\title{
Effect of arsenic (As) and lead (Pb) on glycogen content and on the activities of selected enzymes involved in carbohydrate metabolism in freshwater catfish, Heteropneustes fossilis
}

\author{
Kermi-u Tariang $\cdot$ Sunkam N. Ramanujam • Bidyadhar Das
}

Received: 10 January 2019/Accepted: 20 July 2019/Published online: 29 July 2019

(C) The Author(s) 2019

\begin{abstract}
Heavy metals show a wide range of effect on fishes, out of which arsenic (As) and lead $(\mathrm{Pb})$ are among the leading heavy metal toxicants. These heavy metals are known to alter different biochemical parameters, including glycogen level, in different tissues of fishes. Glycogen level in fish serves as the main source of energy; hence, in this study, the acute toxicity test of As and $\mathrm{Pb}$ and their effect on the glycogen content and the enzymes involved therein (glycogen phosphorylase, glycogen synthase, hexokinase, phosphofructokinase and pyruvate kinase) were studied in the liver and muscle tissues of Heteropneustes fossilis. The $96 \mathrm{~h} \mathrm{LC}_{50}$ values of $\mathrm{As}_{2} \mathrm{O}_{3}$ and $\mathrm{PbCl}_{2}$ on $\mathrm{H}$. fossilis were found to be $35.09 \mathrm{ppm}$ and $66.20 \mathrm{ppm}$, respectively. On acute exposure to $96 \mathrm{~h} \mathrm{LC}_{50}$ values of $\mathrm{As}_{2} \mathrm{O}_{3}$ and $\mathrm{PbCl}_{2}$, the glycogen concentration showed a gradual decrease in both liver and muscle tissues of $H$. fossilis. However, on chronic exposure $\left(\mathrm{LC}_{50} / 20\right.$ th ppm), the glycogen content in liver and muscle of $H$. fossilis was depleted till 20 days; whereas after 30 days, the glycogen level was recovered in both the tissues. The activities of glycogen metabolic enzymes (glycogen phosphorylase and glycogen synthase) and few selected glycolytic enzymes (hexokinase, phosphofructokinase and pyruvate kinase) were also altered in $H$. fossilis when exposed to acute and chronic concentration of $\mathrm{As}_{2} \mathrm{O}_{3}$ and $\mathrm{PbCl}_{2}$. Our present results showed that $\mathrm{As}$ and $\mathrm{Pb}$ induced toxicity stress on the catfish, H. fossilis, which might have caused to alter the carbohydrate metabolism in the fish.
\end{abstract}

Keywords Arsenic $\cdot$ Lead $\cdot$ H. fossilis $\cdot$ Glycogen $\cdot$ GPase $\cdot$ GSase

\section{Introduction}

Freshwater gets contaminated with different pollutants and is a matter of concern (Vinodhini and Narayanan 2009). Among the various water pollutants, heavy metals pose a great threat to fishes. The natural aquatic systems are contaminated with heavy metals released from domestic, industrial, and other man-made activities (Velez and Montoro 1998). These heavy metals cause the greatest threat to the health of the aquatic ecosystem (Ohe et al. 2004; Govind and Madhuri 2014), as well as human health (Wennberg 1994). Arsenic (As) and lead $(\mathrm{Pb})$ are recognized as the leading toxicants worldwide (Akhtar et al. 2013), and these heavy metals are accumulated in different tissues, and the rate of their accumulation is in the order of muscle $>$ liver $>$ gill for As, and of gill $>$ liver $>$ muscle for $\mathrm{Pb}$ (Thang et al. 2017). These heavy metals cause serious damage to aquatic life, including fishes (Karbassi et al. 2006).

K. Tariang $\cdot$ S. N. Ramanujam · B. Das $(\bowtie)$

Department of Zoology, North-Eastern Hill University, Shillong 793022, India

e-mail: dasbidyadhar@gmail.com 
Glycogen is the main source of energy for animals and its content in the liver and muscle indicates the health of the fish. The rate of glycogen synthesis is a function of the relative activities of glycogen synthase (GSase) and glycogen phosphorylase (GPase). Both GPase and GSase exist in two interconvertible forms, active $(a)$ and less active $(b)$. GPase $a$ catalyzes the rate-limiting step of glycogenolysis, and control glycogenesis (Connett and Sahlin 1996). Both $\mathrm{As}$ and $\mathrm{Pb}$ decrease the level of glycogen in Oreochromis mossambicus, and Labeo rohita (James et al. 1996; Aruljothi et al. 2013), and a higher concentration of As induces glycogenolysis in the liver of Channa punctatus (Haque et al. 2009). Glycogenolysis is catalysed by As in rabbit muscle by producing unstable glucose-1-arsenate (Klein et al. 1982); whereas, $\mathrm{Pb}$ decreases the activity of GSase in rat liver, thus decreases the glycogen content (Hacker et al. 1990).

Glucose is oxidized via the glycolytic pathway for the production of ATPs. Glycolytic pathway is inhibited by $\mathrm{As}$ and $\mathrm{Pb}$ by inhibiting hexokinase (Lagunas 1980; Yun and Hoyer 2000) and pyruvate kinase activity (Lepper et al. 2010) in a rat model. The sub-lethal exposure of $\mathrm{Pb}$ decreases the activity of phosphofructokinase activity in the diencephalon, cerebrum, medulla oblongata, and cerebellum of L. rohita, Clarias batrachus and C. punctatus (Raibole et al. 2013).

The Indian catfish, Heteropneustes fossilis (Bloch, 1794), is one of the most economically important food fishes in the Indian subcontinent and Southeast Asian region. This is primarily a fish in ponds, ditches, beels, swamps, and marshes, but sometimes found in muddy rivers (Jha and Rayamajhi 2010; Froese and Pauly 2018). It is hardy and amenable to a high stocking rate and utilizes atmospheric oxygen for respiration (Vijaykumar et al. 1998; Haniffa and Sridhar 2002). H. fossilis is an exceptionally sturdy and long-lived species; therefore, it served as the best model of study. Hence, in the present study, the effect of As and $\mathrm{Pb}$ (both acute and chronic concentrations) on glycogen content and the activities of selected enzymes involved in glycogen metabolism (GPase and GSase) and glucose oxidation (hexokinase, phosphofructokinase, and pyruvate kinase) in both liver and muscle tissues of $H$. fossilis were investigated.

\section{Materials and methods}

Chemicals

$\mathrm{As}_{2} \mathrm{O}_{3}$ (A1010), $\mathrm{PbCl}_{2}$ (268690), Fructose-6-phosphate (F3627), Aldolase (A2714), Triose phosphate isomerase (T6258), Glycerophosphate dehydrogenase (G6751), Glucose 1,6-bisphosphate (G6893), Phosphoglucomutase (P3397) and UDP-glucose (U4625) were purchased from Sigma-Aldrich, St. Louis, USA. HCl (H0090), Sucrose (S2610) and KCl (P0240) were purchased from Rankem, Haryana, India. KOH (GRM1015), $\mathrm{Na}_{2} \mathrm{SO}_{4}$ (MB209), $\mathrm{NaOH}$ (RM467), Tris (RM262), EDTA (RM3915), $\mathrm{MgCl}_{2}$ (MB237), 2-mercaptoethanol (MB041), Triton X-100 (RM845), D-glucose (MB037), NADP ${ }^{+}$(RM392), ATP (RM439), G6PDH (RM7066), NADPH (RM 576), Imidazole (RM1864), Phosphoenolpyruvate (RM9768), NADH (RM393), ADP (RM437), $\mathrm{MgSO}_{4}$ (GRM1281), NaF (GRM7502), EGTA (MB130), PMSF (MB144), $\mathrm{KH}_{2} \mathrm{PO}_{4}(\mathrm{MB} 050), \mathrm{K}_{2} \mathrm{HPO}_{4}$ (RM168), AMP (CMS438), Glycogen (RM9593), Caffein (RM1056), Pyruvate kinase (RM7427), Glucose 6-phosphate (RM378), Comassie Brilliant Blue (RM1219) and $\mathrm{H}_{3} \mathrm{PO}_{4}$ (AS011) were purchased from Himedia, Mumbai, India. LDH (53110) was purchased from Super Religare Laboratories Limited, Mumbai India.

Fishes

The experimental fish, H. fossilis, with an average weight of $25 \pm 2 \mathrm{~g}$ and length of $15 \pm 2 \mathrm{~cm}$, were procured from commercial sources and acclimatized to laboratory conditions in dechlorinated water for 15 days in a plastic tank. The acclimatized fishes were then used for subsequent experiments.

$\mathrm{LC}_{50}$ determination

Toxicity tests were performed in accordance to the standard methods mentioned in the Organization for Economic Co-operation and Development (OECD 1992). These tests were carried out in plastic tanks containing $8 \mathrm{~L}$ of water and 10 fishes for each group. Following the preliminary screening, different 
concentrations of $\mathrm{As}_{2} \mathrm{O}_{3}$ (25 ppm to $50 \mathrm{ppm}$ ) and $\mathrm{PbCl}_{2}$ (50 ppm to $100 \mathrm{ppm}$ ) were used for bioassay with an independent simultaneous maintenance of control. Feeding was stopped $24 \mathrm{~h}$ prior to the treatment and during the experiment. The fishes were exposed to different concentrations of $\mathrm{As}_{2} \mathrm{O}_{3}$ and $\mathrm{PbCl}_{2}$ for $96 \mathrm{~h}$, and the mortality percentage was recorded at $24 \mathrm{~h}, 48 \mathrm{~h}, 72 \mathrm{~h}$ and $96 \mathrm{~h}$ post exposure. $\mathrm{LC}_{50}$ values for $\mathrm{As}$ and $\mathrm{Pb}$ were calculated by Probit analysis method using Statistical Package for the Social Sciences (SPSS) 17.0 software.

The fishes were then treated with both acute $\left(35.09 \mathrm{ppm} \mathrm{As}_{2} \mathrm{O}_{3}\right.$ and $\left.66.20 \mathrm{ppm} \mathrm{PbCl}_{2}\right)$ and chronic $\left(\mathrm{LC}_{50} /\right.$ 20th ppm of both $\mathrm{As}_{2} \mathrm{O}_{3}$ and $\mathrm{PbCl}_{2}$ ) concentrations of $\mathrm{As}$ and $\mathrm{Pb}$ for the estimation of glycogen content and to study the activities of the selected enzymes (glycogen phosphorylase, glycogen synthase, hexokinase, phosphofructokinase and pyruvate kinase) of $H$. fossilis.

Estimation of glycogen content

The glycogen content in different tissues of $H$. fossilis was estimated following the method as described by Seifter et al. (1949). In brief, $1 \mathrm{~g}$ of fish tissues was taken in $3 \mathrm{ml}$ of $30 \% \mathrm{KOH}$ solution and boiled for $20 \mathrm{~min}$. After adding $2 \mathrm{ml}$ of saturated $\mathrm{Na}_{2} \mathrm{SO}_{4}$ and $3 \mathrm{ml}$ of $95 \%$ ethanol, the homogenate was boiled for 20 min and centrifuged at $3000 \mathrm{~g}$ for $5 \mathrm{~min}$. The pellet was dissolved in $2 \mathrm{ml}$ of water and $6 \mathrm{ml}$ of $90 \%$ ethanol and boiled for $10 \mathrm{~min}$. The precipitate was redissolved in $3 \mathrm{ml}$ water and $3 \mathrm{ml}$ of $2 \mathrm{~N} \mathrm{HCl}$ and was boiled for 30 min. Prior to the estimation of glycogen, the solution was neutralized by adding $3 \mathrm{ml}$ of $1 \mathrm{~N} \mathrm{NaOH}$ and used for the estimation of glycogen. For the estimation of glycogen, $1 \mathrm{ml}$ of the neutralized solution was taken and mixed with $3 \mathrm{ml}$ of $0.2 \%$ anthrone reagent (prepared in concentrated $\mathrm{H}_{2} \mathrm{SO}_{4}$ ) and boiled for 15 min. After cooling down, the OD was taken at $620 \mathrm{~nm}$ using a spectrophotometer (Carry 60, Agilent), and the glycogen content was estimated against a standard glycogen graph.

Transmission electron microscopy (TEM) study

Glycogen content in the liver and muscle tissues of $H$. fossilis was visualized by TEM study. In brief, after treatment, the liver and muscle tissues were cut into small pieces $(1 \mathrm{~mm} \times 1 \mathrm{~mm})$ and were fixed in Karnovsky's fixative for $4 \mathrm{~h}$ (David et al. 1973). The samples were then washed thoroughly in $0.1 \mathrm{M}$ cacodylate buffer and post-fixation was carried out in $1 \%$ osmium tetraoxide for $1 \mathrm{~h}$ at $4{ }^{\circ} \mathrm{C}$. The samples were dehydrated in ascending grades of acetone $(30 \%, 50 \%, 70 \%, 80 \%, 90 \%, 95 \%$, and dry acetone). The acetone was cleared off from the samples by using propylene oxide for $30 \mathrm{~min}$. Embedding of the tissues was carried out in Araldite embedding medium using beam capsule. The embedded blocks were kept at $50{ }^{\circ} \mathrm{C}$ in an embedding oven for $24 \mathrm{~h}$ at $60^{\circ} \mathrm{C}$. Ultra-thin sections $(600-800 \AA)$ were cut in a RMC Ultra-Microtome and the sections were then stained using $50 \%$ alcoholic solution of uranyl acetate for $10 \mathrm{~min}$ at room temperature in the dark, followed by lead nitrate for $5 \mathrm{~min}$ (Reynolds 1963). The stained sections were examined using JOEL JEM 2100 Transmission Electron Microscope at an accelerating voltage of $80 \mathrm{kV}$.

Enzyme assay

\section{Tissue processing}

For assaying the activities of GPase (EC 2.4.1.1) and GSase (EC 2.4.1.11), a 10\% tissue homogenate was prepared in a homogenizing buffer containing $20 \mathrm{mM}$ Imidazole-HCl buffer (pH 7.2), $100 \mathrm{mM} \mathrm{NaF}, 10 \mathrm{mM}$ EDTA, $10 \mathrm{mM}$ EGTA, $15 \mathrm{mM} \beta$-mercaptoethanol, and 0.1 mM PMSF (Russell and Storey 1995). The homogenate was sonicated for 3 cycles of $30 \mathrm{~s}$ ON and $30 \mathrm{~s}$ OFF using Q500 sonicator (Qsonica) for proper breakage of mitochondria. The homogenate was then centrifuged at $10,000 \mathrm{~g}$ for $10 \mathrm{~min}$ followed by $14,000 \mathrm{~g}$ for $30 \mathrm{~min}$ at $4{ }^{\circ} \mathrm{C}$, and the resultant supernatant was used for the enzyme assays.

To determine the activities of hexokinase (EC 2.7.1.1), phosphofructokinase (EC 2.7.1.11) and pyruvate kinase (EC 2.7.1.40), a 10\% tissue homogenate was also prepared in a homogenizing buffer containing $50 \mathrm{mM}$ Tris-HCl buffer (pH 7.4), $0.3 \mathrm{M}$ Sucrose, $1 \mathrm{mM}$ EDTA, $2 \mathrm{mM} \mathrm{MgCl}_{2}$ and $2 \mathrm{mM} \beta$-mercaptoethanol. The homogenate was then treated with $0.5 \%$ Triton X-100 (1:1) for $30 \mathrm{~min}$, followed by sonication for 3 cycles of $30 \mathrm{~s}$ ON and $30 \mathrm{~s}$ OFF using Q500 sonicator (Qsonica). The homogenate was then centrifuged at 
$10,000 \mathrm{~g}$ for $10 \mathrm{~min}$ followed by $14,000 \mathrm{~g}$ for $30 \mathrm{~min}$, and the resultant supernatant was used for the enzyme assays.

\section{Assay of enzyme activities}

The activities of enzymes were assayed spectrophotometrically at $340 \mathrm{~nm}$. In brief, $1 \mathrm{ml}$ of reaction mixture was preincubated at $25^{\circ} \mathrm{C}$ for $5 \mathrm{~min}$. The tissue extract was added to the preincubated reaction mixture in order to start the reaction. OD was recorded at $340 \mathrm{~nm}$ at $30 \mathrm{~s}$ interval for $10 \mathrm{~min}$ and the change in OD values $(\Delta E)$ was taken for calculating the enzyme activity using $6.22 \times 10^{6}$ as molar extinction coefficient value for NADH/NADPH. One unit of enzyme activity was expressed as that amount of enzyme, which catalyzed the oxidation or reduction of $1 \mu \mathrm{mol}$ of coenzymes (NADP ${ }^{+}, \mathrm{NADH}$ and NADPH) per min at $25{ }^{\circ} \mathrm{C}$. The specific activity of the enzymes was expressed as the units of enzyme activity per mg protein.

The reaction mixture for GPase assay contained $60 \mu$ mol potassium phosphate buffer $(\mathrm{pH} 7.2), 50 \mu \mathrm{mol}$ $\mathrm{NADP}^{+}, 5 \mu \mathrm{mol}$ glucose 1,6-bisphosphate, $2.5 \mu \mathrm{mol}$ AMP, 5 units phosphoglucomutase, 5 units G6PDH, $10 \mathrm{mg}$ glycogen, and $50 \mu \mathrm{l}$ tissue extract. The reaction mixture also contained $10 \mu \mathrm{mol}$ caffeine to determine the activity of GPase $a$ alone (Moon et al. 1989). For GSase assay, the reaction mixture contained $60 \mu \mathrm{mol}$ Imidazole- $\mathrm{HCl}$ buffer $(\mathrm{pH} 7.2), 5 \mu \mathrm{mol}$ phosphoenolpyruvate, $6 \mu \mathrm{mol}$ UDP-glucose, $0.15 \mu \mathrm{mol} \mathrm{NADH}$, $150 \mu \mathrm{mol} \mathrm{KCl}, 15 \mu \mathrm{mol} \mathrm{MgCl}_{2}, 2 \mathrm{mg}$ glycogen, 10 units pyruvate kinase, 10 units lactate dehydrogenase, and $50 \mu \mathrm{l}$ tissue extract. The reaction mixture did not contain $5 \mu \mathrm{mol}$ glucose 6-phosphate while measuring the GSase $a$ activity alone (Passonneau and Rottenberg 1973).

The activity of hexokinase was assayed following the method as described by Bergmeyer (1974). $1 \mathrm{ml}$ of reaction mixture contained $50 \mu \mathrm{mol}$ Tris- $\mathrm{HCl}$ buffer ( $\mathrm{pH} 7.4$ ), $5 \mu \mathrm{mol}$ D-glucose, $0.2 \mu \mathrm{mol} \mathrm{NADP}{ }^{+}, 0.9 \mu \mathrm{mol}$ ATP, $5 \mu \mathrm{mol} \mathrm{MgCl}_{2}, 10$ units G6PDH, and $50 \mu \mathrm{l}$ tissue extract. The activity of phosphofructokinase was assayed following the method as described by Buckwitz et al. (1988). $1 \mathrm{ml}$ of reaction mixture contained $80 \mu \mathrm{mol}$ Tris- $\mathrm{HCl}(\mathrm{pH}$ 7.2), $5 \mu \mathrm{mol}$ fructose 6-phosphate, $0.2 \mu \mathrm{mol}$ NADPH, $0.8 \mu \mathrm{mol}$ ATP, $0.9 \mu \mathrm{mol}$ $\mathrm{MgCl}_{2}, 90 \mu \mathrm{mol} \mathrm{KCl}, 1 \mu \mathrm{mol} \mathrm{K} \mathrm{HPO}_{4}, 8.0 \mu \mathrm{g}$ aldolase, $3.3 \mu \mathrm{g}$ triose phosphate isomerase, $3.3 \mu \mathrm{g}$ glycerophosphate dehydrogenase and $50 \mu$ tissue extract. The activity of pyruvate kinase was assayed following the method as described by Bücher and Pfleiderer (1955). $1 \mathrm{ml}$ of reaction mixture contained $50 \mu \mathrm{mol}$ Imidazole-HCl buffer ( $\mathrm{pH}$ 7.6), $5 \mu \mathrm{mol}$ phosphoenolpyruvate, $0.2 \mu \mathrm{mol} \mathrm{NADH}, 1.5 \mu \mathrm{mol}$ ADP, $120 \mu \mathrm{mol}$ $\mathrm{KCl}, 30 \mu \mathrm{mol} \mathrm{MgSO}_{4}, 10$ units lactate dehydrogenase, and $50 \mu \mathrm{l}$ tissue extract.

Statistical analysis

The data were obtained from at least three different experiments and statistically analyzed and presented as mean \pm SEM. Mean values of the control and the treated samples were then compared using one way ANOVA using Statistical Package for the Social Sciences 17.0 software by Turkey post-hoc analyses with $p<0.05$ regarded as statistically significant.

\section{Results}

Acute toxicity test

The acute toxicity test was performed in order to evaluate the toxicity of $\mathrm{As}$ and $\mathrm{Pb}$ on $H$. fossilis. The percentage mortality of $H$. fossilis during the exposure time at $48 \mathrm{~h}, 72 \mathrm{~h}$ and $96 \mathrm{~h}$, respectively, was determined and indicated in Fig. 1 (A, B), which showed that the mortality of the fish was increased with increasing $\mathrm{As}_{2} \mathrm{O}_{3}$ and $\mathrm{PbCl}_{2}$ concentration. The $96 \mathrm{~h} \mathrm{LC} 50$ values of $\mathrm{As}_{2} \mathrm{O}_{3}$ were calculated and was found to be $35.097 \mathrm{ppm}$; whereas, that of $\mathrm{PbCl}_{2}$ was $66.205 \mathrm{ppm}$. Based on these findings, the $96 \mathrm{~h} \mathrm{LC}_{50}$ values of $\mathrm{As}_{2} \mathrm{O}_{3}$ and $\mathrm{PbCl}_{2}$ were taken for acute study; whereas, the $\mathrm{LC}_{50} / 20$ th ppm values were taken for chronic study for estimating the glycogen content and the activities of selected enzymes as mentioned before involved in glycogen metabolism and glycolysis. 

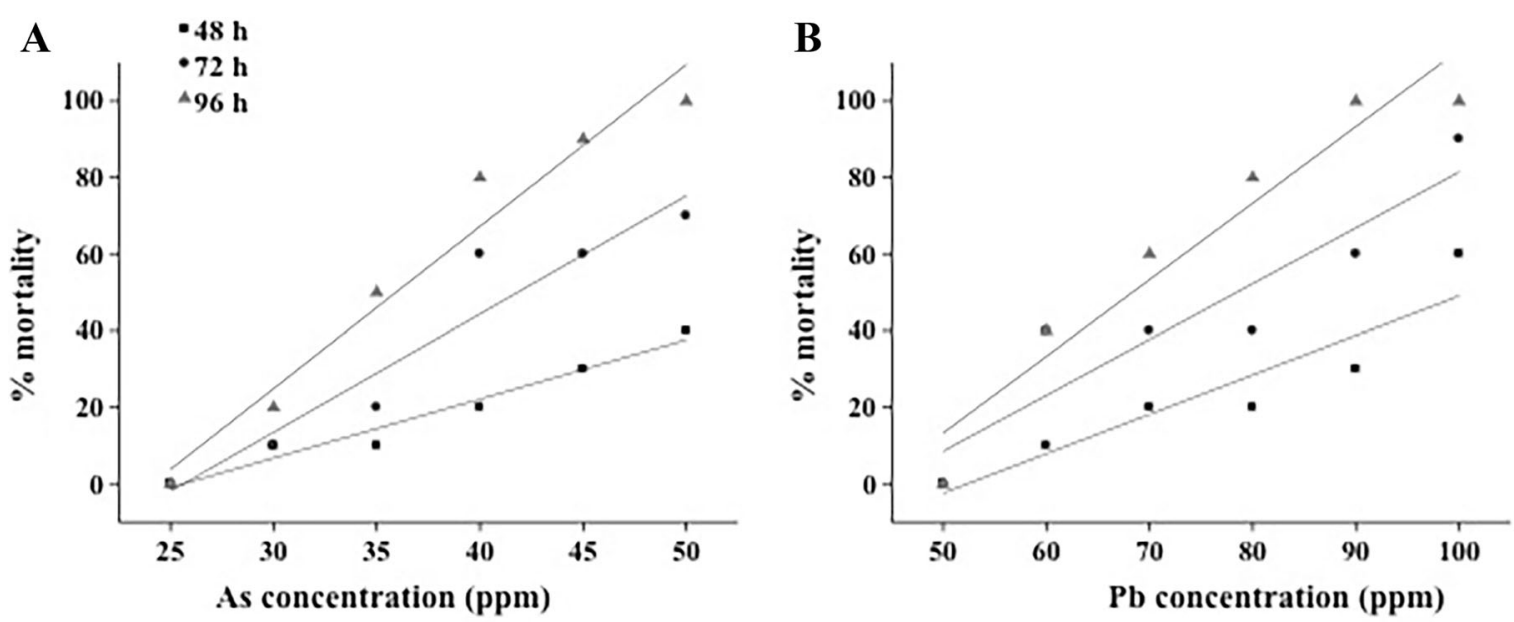

Fig. 1 Determination of $48 \mathrm{~h}, 72 \mathrm{~h}$, and $96 \mathrm{~h} \mathrm{LC}$ 50 values of $H$. fossilis exposed to $\mathrm{As}_{2} \mathrm{O}_{3}$ (a) and $\mathrm{PbCl}_{2}$ (b)

Estimation of glycogen

The glycogen content in liver and muscle tissues of $\mathrm{H}$. fossilis was estimated for both acute and chronic treatment of $\mathrm{As}_{2} \mathrm{O}_{3}$ and $\mathrm{PbCl}_{2}$ and presented in Table 1. Following the acute treatment of both $\mathrm{As}_{2} \mathrm{O}_{3}$ and $\mathrm{PbCl}_{2}$, the glycogen content showed a gradual decrease in both liver and muscle tissues of $H$. fossilis. There was a significant decrease in the glycogen level (approximately 50-60\%) within $96 \mathrm{~h}$ of $\mathrm{As}_{2} \mathrm{O}_{3}$ and $\mathrm{PbCl}_{2}$ acute treatment as compared to the control. However, upon chronic treatment of $\mathrm{As}_{2} \mathrm{O}_{3}$ and $\mathrm{PbCl}_{2}$, the glycogen content decreased up to $30-50 \%$ till 20 days, then there was a sudden increase in the glycogen level on 30 days. In corroboration to biochemical analysis of glycogen content, TEM studies were performed to find out the changes in the glycogen content in both liver and muscle tissues of $H$. fossilis exposed to $96 \mathrm{~h} \mathrm{LC}_{50}$ values of $\mathrm{As}_{2} \mathrm{O}_{3}$ and $\mathrm{PbCl}_{2}$. TEM studies of liver and muscle tissues of $H$. fossilis showed that the glycogen granules were decreased when exposed to an acute concentration of $\mathrm{As}_{2} \mathrm{O}_{3}$ and $\mathrm{PbCl}_{2}$. Along with the decrease in glycogen level in the liver and muscle tissues of the catfish, the liver cells also showed a degenerated cell membrane, broken endoplasmic reticulum, disoriented nucleus, and dense mitochondria (Fig. 2a-c). Similarly, broken myofibrils were also observed in the muscle cells of the treated catfish exposed to heavy metals (Figs. 2d-f).

Effect of $\mathrm{As}$ and $\mathrm{Pb}$ on the activities of glycogen metabolic enzymes

The specific activity of GPase $a+b$ in the liver of $H$. fossilis did not show any significant changes on acute and chronic treatment of $\mathrm{As}_{2} \mathrm{O}_{3}$ and $\mathrm{PbCl}_{2}$ (Table 2). However, the specific activity of GPase $a$ in liver was increased by $61.54 \%$ and $53.85 \%$ upon acute treatment with $\mathrm{As}_{2} \mathrm{O}_{3}$ and $\mathrm{PbCl}_{2}$, respectively; whereas, upon chronic treatment with $\mathrm{As}_{2} \mathrm{O}_{3}$ and $\mathrm{PbCl}_{2}$, the specific activity of GPase $a$ in liver of $H$. fossilis was increased by $56.25 \%$ and $50.00 \%$, respectively, after 20 days. But, after 30 days of treatment, the specific activity of GPase $a$ in liver of $H$. fossilis did not show any significant changes (Table 2). The specific activity of GSase $a+b$ in liver of $H$. fossilis also did not show any significant changes upon acute and chronic treatment with $\mathrm{As}_{2} \mathrm{O}_{3}$ and $\mathrm{PbCl}$ (Table 2). However, upon acute treatment of $\mathrm{As}_{2} \mathrm{O}_{3}$ and $\mathrm{PbCl}_{2}$, the specific activity of GSase $a$ was decreased by $70.00 \%$ and $57.50 \%$, respectively; however, upon chronic treatment of $\mathrm{As}_{2} \mathrm{O}_{3}$ and $\mathrm{PbCl}_{2}$, the specific activity of GSase $a$ was decreased by $47.27 \%$ and $50.91 \%$, respectively, after 20 days, but it showed slightly recovery after 30 days (Table 2 ).

The specific activity of GPase $a+b$ in the muscle of $H$. fossilis also did not show any significant changes (Table 3). Upon acute treatment with $\mathrm{As}_{2} \mathrm{O}_{3}$ and $\mathrm{PbCl}_{2}$, the specific activity of GPase $a$ in the muscle of $H$. fossilis was increased by $66.67 \%$ and $75.00 \%$, respectively. However, upon chronic treatment of $\mathrm{As}_{2} \mathrm{O}_{3}$ and $\mathrm{PbCl}_{2}$, the specific activity of GPase $a$ in the muscle of $H$. fossilis was also increased by $81.82 \%$ and $72.73 \%$, respectively, on 20 days; however, after 30 days of treatment, the specific activity GPase $a$ was recovered and 


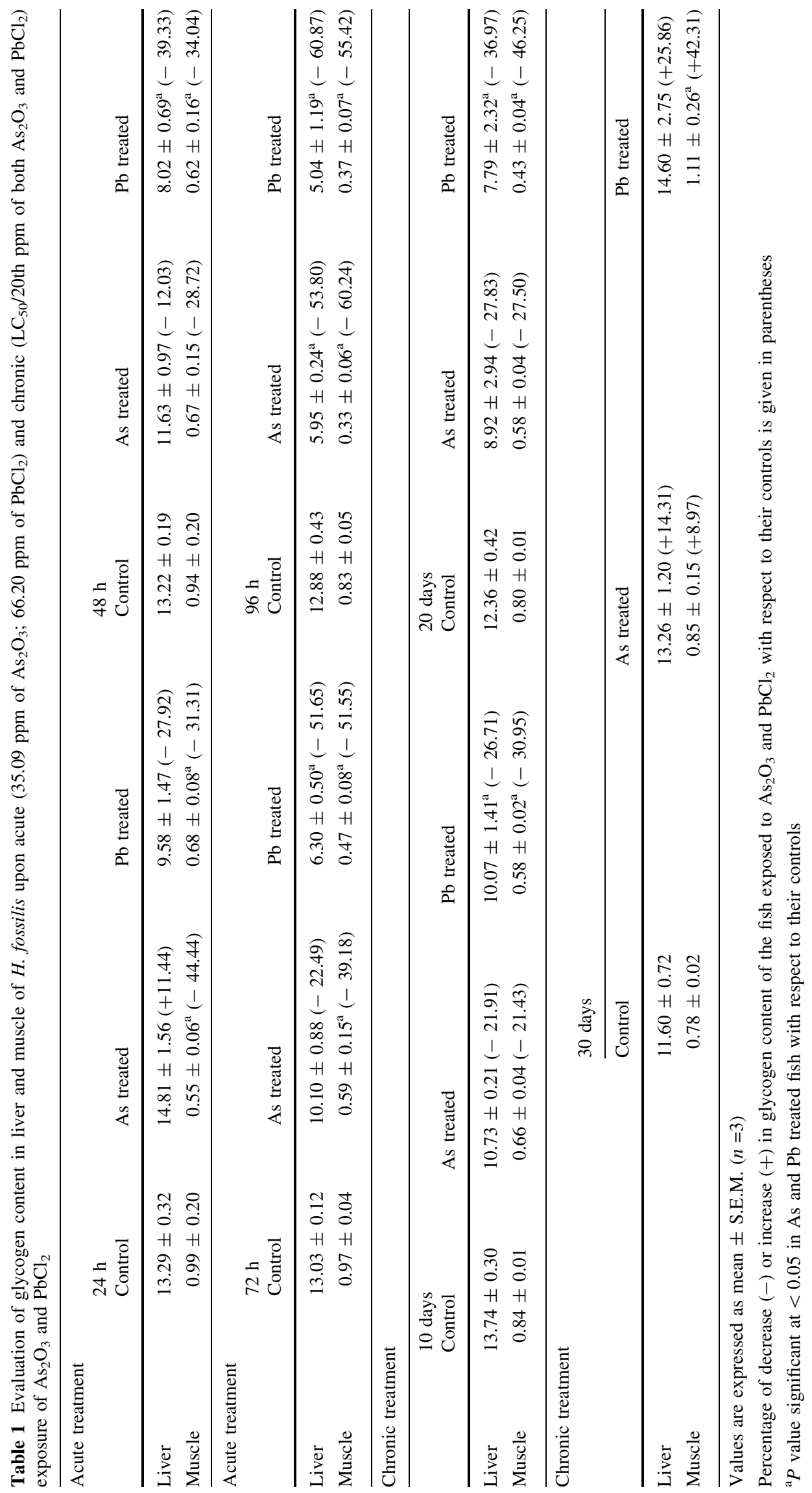



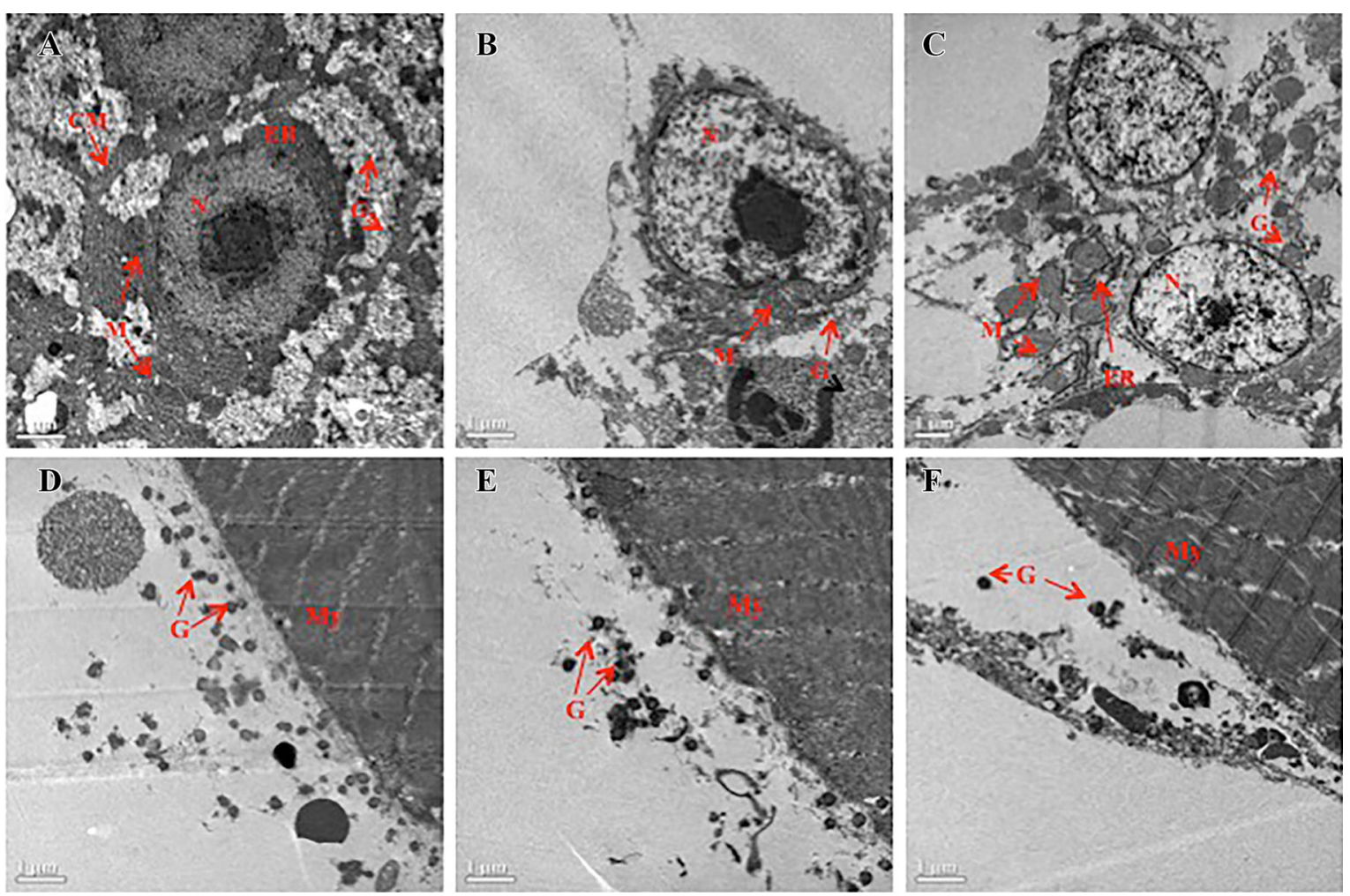

Fig. 2 Effect of $\mathrm{As}_{2} \mathrm{O}_{3}$ and $\mathrm{PbCl}_{2}$ on glycogen particles in liver $(\mathbf{a}-\mathbf{c})$ and muscle $(\mathbf{d}-\mathbf{f})$ tissues of $H$. fossilis. The catfish was treated with $\mathrm{LC}_{50}$ values of $\mathrm{As}_{2} \mathrm{O}_{3}$ and $\mathrm{PbCl}_{2}$ and glycogen particles were observed using transmission electron microscopy. a Control; b exposed to $35.09 \mathrm{ppm} \mathrm{As}_{2} \mathrm{O}_{3}$ for $\sim 96 \mathrm{~h}$; $\mathbf{c}$ exposed to $66.20 \mathrm{PbCl}_{2}$ for $\sim 96 \mathrm{~h}$; $\mathbf{d}$ control; e exposed to $35.09 \mathrm{ppm}$ $\mathrm{As}_{2} \mathrm{O}_{3}$ for $\sim 96 \mathrm{~h} ; \mathbf{f}$ exposed to $66.20 \mathrm{PbCl}_{2}$ for $\sim 96 \mathrm{~h}$. $C M$ cell membrane, $E R$ endoplasmic reticulum, $G$ glycogen granules, $M$ mitochondria, $M y$ myofibrils, $N$ nucleus

showed no significant changes when compared to the control (Table 3). In the muscle of $H$. fossilis, the specific activity of GSase $a+b$ did not show any significant changes upon acute and chronic treatment with $\mathrm{As}_{2} \mathrm{O}_{3}$ and $\mathrm{PbCl}_{2}$ (Table 3). The specific activity of GSase $a$ in the muscle of $H$. fossilis was decreased by $57.58 \%$ and 53.03\% upon acute treatment of $\mathrm{As}_{2} \mathrm{O}_{3}$ and $\mathrm{PbCl}_{2}$, respectively; however, upon chronic treatment with $\mathrm{As}_{2} \mathrm{O}_{3}$ and $\mathrm{PbCl}_{2}$, the specific activity of GSase $a$ in the muscle of $H$. fossilis was decreased by $47.76 \%$ and $52.24 \%$, respectively, up to 20 days (Table 3 ).

Effect of $\mathrm{As}$ and $\mathrm{Pb}$ on activities of selected glycolytic enzymes

The effect of $\mathrm{As}$ and $\mathrm{Pb}$ was also tested on the activities of selected glycolytic enzymes. The specific activity of hexokinase in the liver of $\mathrm{H}$. fossilis was decreased by $69.70 \%$ and $59.09 \%$ upon acute exposure with $\mathrm{As}_{2} \mathrm{O}_{3}$ and $\mathrm{PbCl}_{2}$, respectively; however, upon chronic treatment, the specific activity of hexokinase in the liver of $H$. fossilis was decreased gradually up to $62.07 \%$ and $60.34 \%$, respectively (Table 4). The specific activity of phosphofructokinase in the liver of $H$. fossilis did not show any significant changes when treated with both acute and chronic concentration of $\mathrm{As}_{2} \mathrm{O}_{3}$ and $\mathrm{PbCl}_{2}$ (Table 4). The specific activity of pyruvate kinase in the liver of $H$. fossilis was decreased by $51.12 \%$ and $65.59 \%$ upon acute treatment with $\mathrm{As}_{2} \mathrm{O}_{3}$ and $\mathrm{PbCl}_{2}$, respectively. On chronic treatment with $\mathrm{As}_{2} \mathrm{O}_{3}$ and $\mathrm{PbCl}_{2}$, the specific activity of pyruvate kinase in the liver of $\mathrm{H}$. fossilis was also found to be decreased gradually up to $49.81 \%$ and $46.41 \%$, respectively (Table 4 ).

The specific activity of hexokinase in the muscle of $\mathrm{H}$. fossilis was decreased by $50.00 \%$ and $55.26 \%$ on acute treatment of $\mathrm{As}_{2} \mathrm{O}_{3}$ and $\mathrm{PbCl}_{2}$, respectively. However, upon chronic treatment of $\mathrm{As}_{2} \mathrm{O}_{3}$ and $\mathrm{PbCl}_{2}$, the specific activity of hexokinase was decreased gradually up to $44.83 \%$ and $41.38 \%$, respectively (Table 5). The specific activity of phosphofructokinase in the muscle of $\mathrm{H}$. fossilis, showed no significant changes on both acute and chronic treatment of $\mathrm{As}_{2} \mathrm{O}_{3}$ and $\mathrm{PbCl}_{2}$ (Table 5). However, in the muscle of $H$. fossilis, the specific 


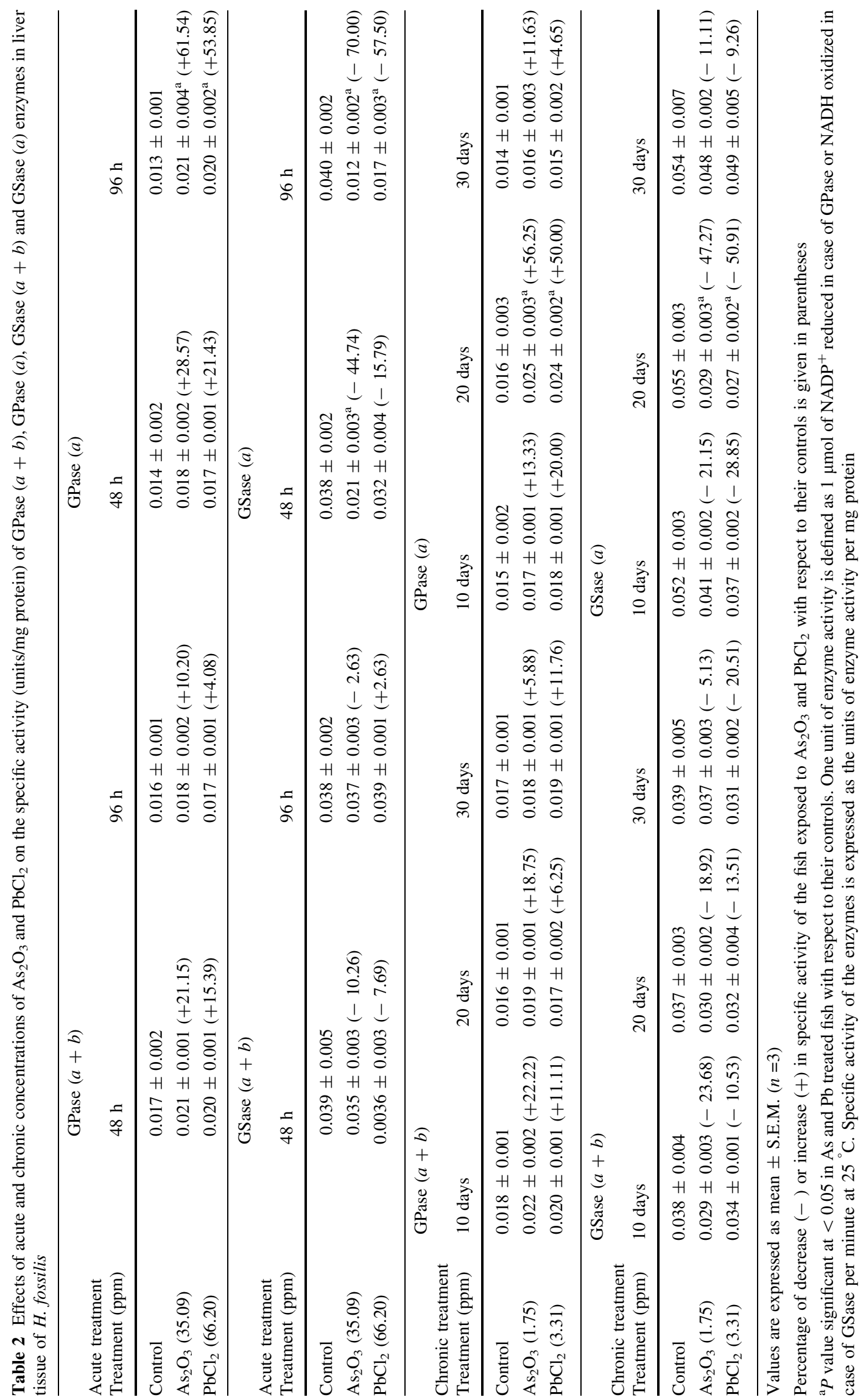




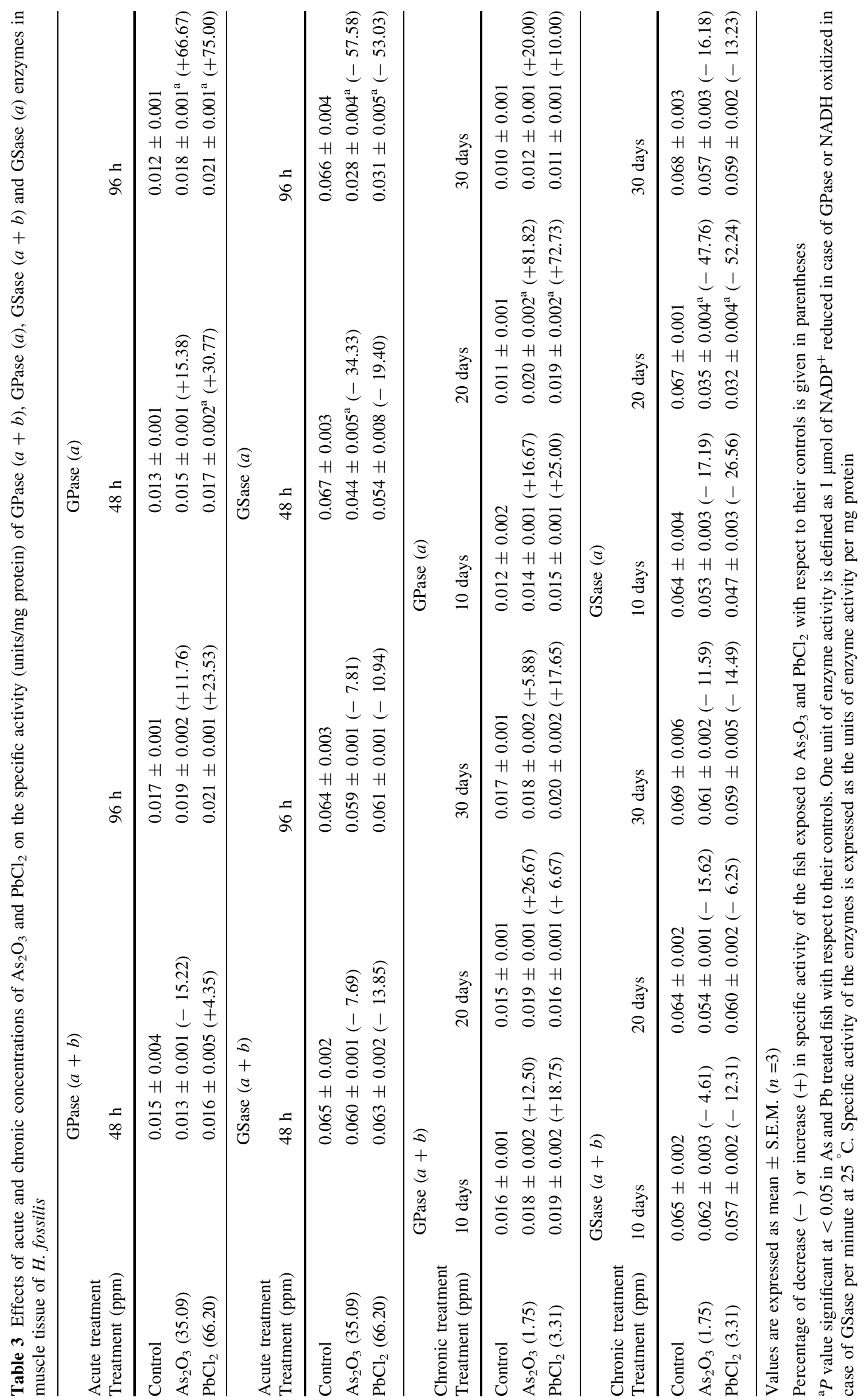




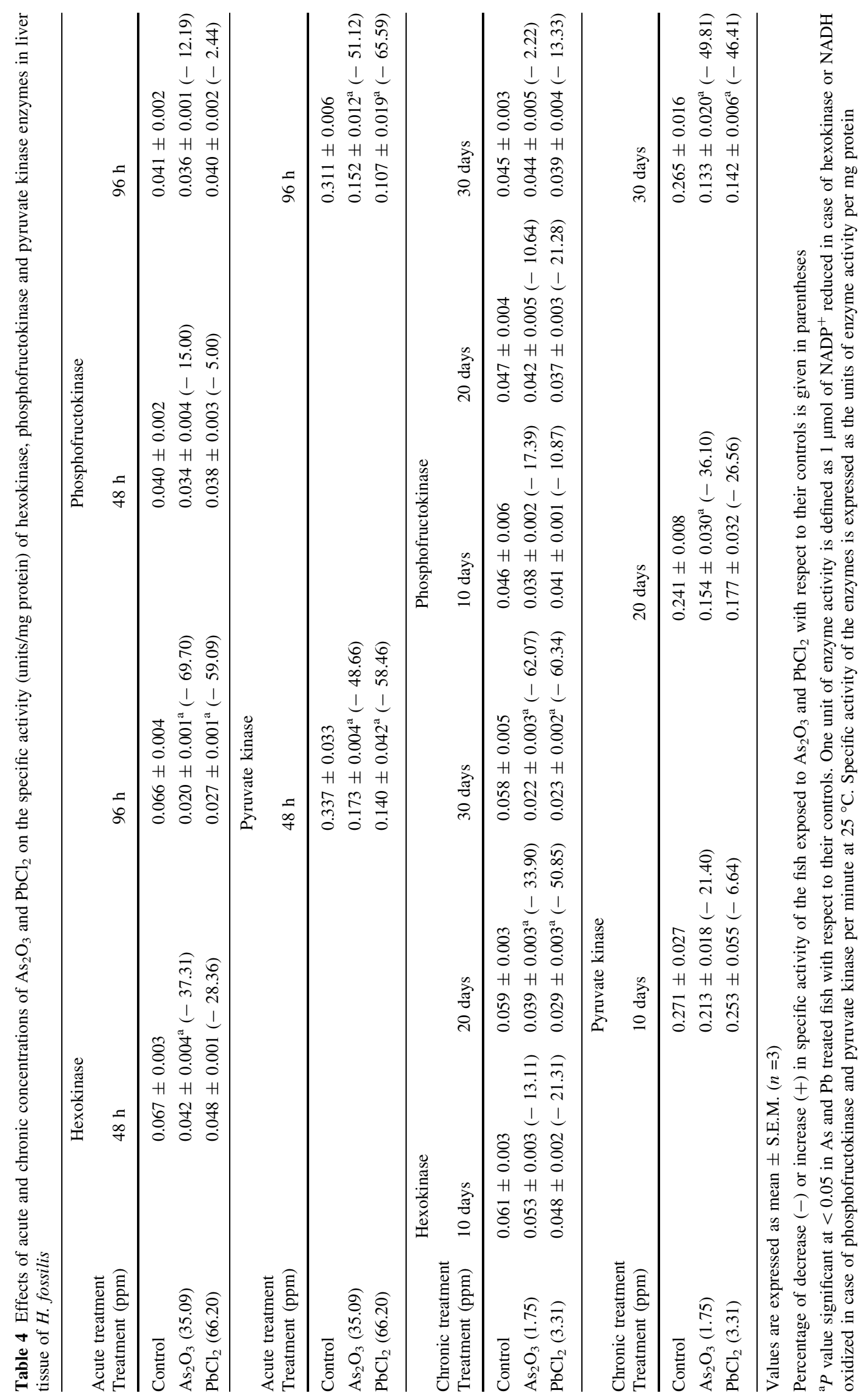




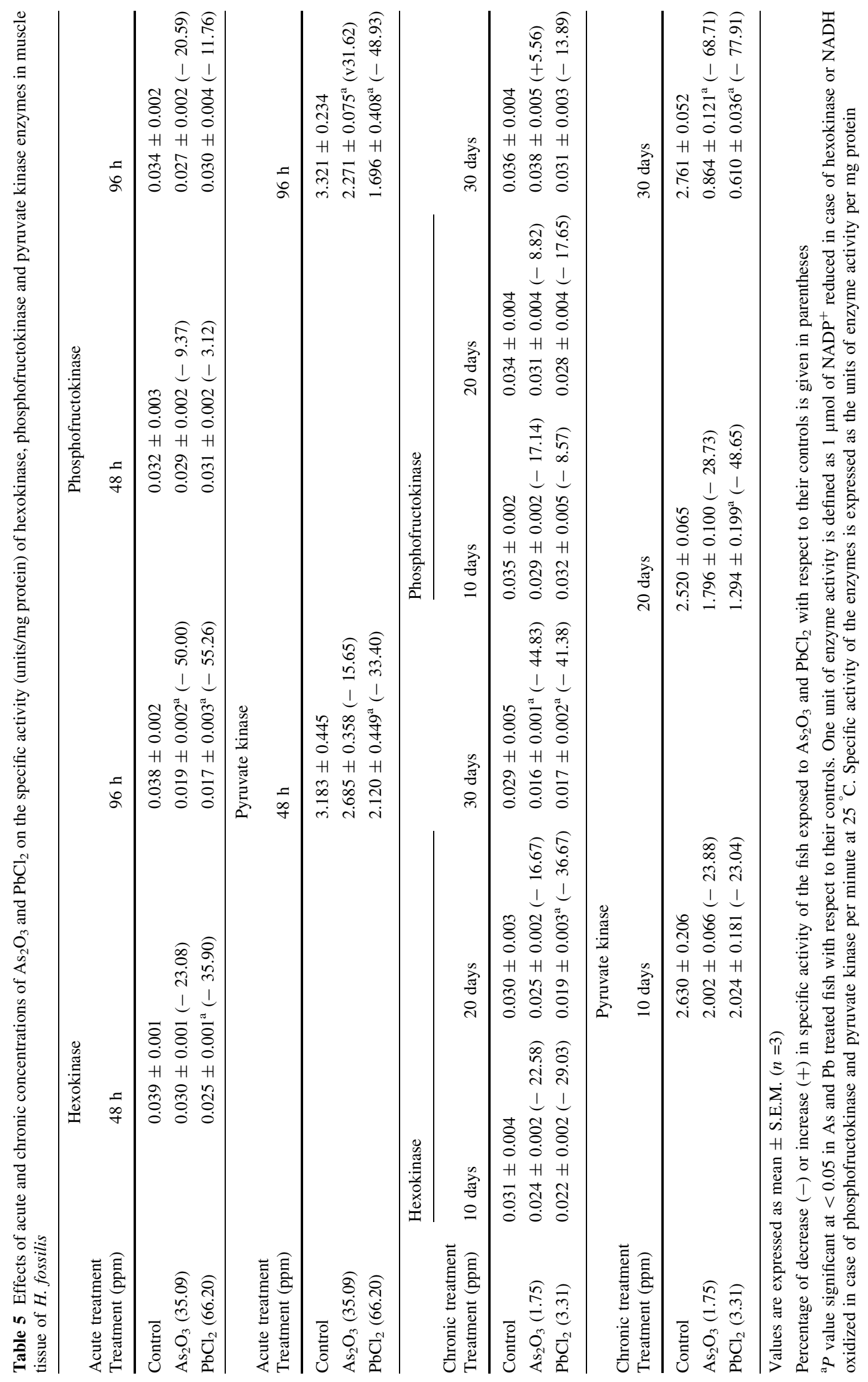


activity of pyruvate kinase was decreased by $31.62 \%$ and $48.93 \%$ upon acute treatment of $\mathrm{As}_{2} \mathrm{O}_{3}$ and $\mathrm{PbCl}_{2}$, respectively; whereas, upon chronic treatment of $\mathrm{As}_{2} \mathrm{O}_{3}$ and $\mathrm{PbCl}_{2}$, the specific activity of pyruvate kinase was observed to be decreased gradually up to $68.71 \%$ and $77.91 \%$, respectively (Table 5).

\section{Discussion}

Sensitivity of fish to As and $\mathrm{Pb}$ differs among different species of fishes. A possible explanation for these differences to trace metals might be explained as a function of metallothionein synthesis, which is believed to provide a protective role against toxic effect of metals in aquatic animals including fishes (Roesijadi 1992; Hollis et al. 2001). Acute toxicity tests were conducted to determine $\mathrm{LC}_{50}$ values of $\mathrm{As}_{2} \mathrm{O}_{3}$ and $\mathrm{PbCl}_{2}$ on $H$. fossilis and it was found to be $35.097 \mathrm{ppm}$ and $66.205 \mathrm{ppm}$, respectively. Earlier findings show that $96 \mathrm{~h} \mathrm{LC}_{50}$ of $\mathrm{As}_{2} \mathrm{O}_{3}$ is $8.91 \mathrm{ppm}$ for Danio rerio (Bhavani and Karuppasamy 2014), $24.19 \mathrm{ppm}$ for Chana punctatus (Amsath et al. 2017), $49.5 \mathrm{ppm}$ for Poecilia sphenops (Patel et al. 2017), and $18.21 \mathrm{ppm}$ for Anabas testudineus (Akter et al. 2008). Previous studies also show that the $96 \mathrm{~h} \mathrm{LC}_{50}$ of $\mathrm{PbCl}_{2}$ is $1.01 \mathrm{ppm}$ for Anabas testudineus (Parvin et al. 2011), $58.0 \mathrm{ppm}$ for Cyprinus carpio (Hedayati et al. 2013) and $86.84 \mathrm{ppm}$ for Metynnis fasciatus (Sadeghi and Imanpoor 2015).

In the present study, acute and chronic exposure of $H$. fossilis to $\mathrm{As}$ and $\mathrm{Pb}$ exhibited significant alterations in the glycogen content in the liver and muscle tissues of $H$. fossilis. Glycogen granules were shown to be depleted in the fish exposed to an acute concentration of heavy metals (As and $\mathrm{Pb}$ ) as evidenced from the TEM studies. Depletion in glycogen granules in liver of zebra fish is also reported by Macirella et al. (2016) when treated with mercury chloride. The depletion of glycogen may be due to rapid turnover of the glycogen. Ananth et al. (2014) and Kavidha and Muthulingam (2014) have also reported the decline of glycogen content in grass carps, Ctenopharyngodon idella and Cyprinus carpio when exposed to As and $\mathrm{Pb}$. Exposure to chronic concentrations of $\mathrm{As}$ and $\mathrm{Pb}$ showed that the glycogen content was decreased up to 20 days, but after 20 days there was an increase in glycogen content in both liver and muscle tissues of the fish. Similar trend has also been reported by Sastry and Subhadra (1982) in H. fossilis when exposed to cadmium. This may be due to the reduced rates of glycogenolysis resulting from the cumulative toxic effects of $\mathrm{As}$ and $\mathrm{Pb}$.

The decreasing glycogen content in both liver and muscle tissues of the fish was resulted by the increasing specific activity of GPase $a$. Upon acute treatment of As and $\mathrm{Pb}$, GPase $a$ specific activity increases, which correspond with the breakdown of glycogen granules in both liver and muscle tissues of Clarias batrachus (Begum 2004). However, upon chronic exposure to As and Pb the specific activity of GPase $a$ was increased after 20 days of treatment, and recovered after 30 days, which may be correlated with the rapid restoration of glycogen content in both the tissues. In the present study, the decrease in the specific activities of GSase $a$ in liver and muscle tissues of $H$. fossilis may be correlated with the increase in glycogenolysis. Similar results are also observed when Salmo salar is exposed to cadmium (Soengas et al. 1996).

In this study, the specific activity of hexokinase was decreased when exposed to an acute concentrations of As and $\mathrm{Pb}$. Carvalho and Fernandes (2008) show that hexokinase activity in Prochilodus lineatus decreases when exposed to copper. The specific activity of phosphofructokinase showed no significant changes when treated with $\mathrm{As}$ and $\mathrm{Pb}$, which is similar to the effect of copper in Salmo trutta (Beaumont et al. 2000). Pyruvate kinase specific activity was found to decrease when exposed to acute and chronic concentrations of As and $\mathrm{Pb}$. Previous studies also indicate that heavy metals such as copper inhibits pyruvate kinase specific activity in tropical fish, Prochilodus lineatus (Carvalho and Fernandes 2008).

\section{Conclusions}

The results of the present study indicated that $\mathrm{As}$ and $\mathrm{Pb}$ caused significant changes in carbohydrate metabolism in the fish and these alterations could be attributed to the toxic stress induced by these two heavy metals on the model fish.

Acknowledgements The authors thank to the Department of Zoology, North-Eastern Hill University, Shillong, for providing the necessary facilities to carry out the work. K.T. thanks the Ministry of Tribal Affairs (MoTA), New Delhi, India, for providing 
fellowship under the scheme National Fellowship for Higher Education (NFHE) of ST students. The authors also gratefully acknowledge the facilities and assistance provided by Transmission Electron Microscope Unit, SAIF, NEHU, Shillong.

\section{Compliance with ethical standards}

Conflict of interest The authors declare that there are no conflicts of interest.

Open Access This article is distributed under the terms of the Creative Commons Attribution 4.0 International License (http:// creativecommons.org/licenses/by/4.0/), which permits unrestricted use, distribution, and reproduction in any medium, provided you give appropriate credit to the original author(s) and the source, provide a link to the Creative Commons license, and indicate if changes were made.

\section{References}

Akhtar MS, Chali B, Azam T (2013) Bioremediation of arsenic and lead by plants and microbes from contaminated soil. Res Plant Sci 1:68-73. https://doi.org/10.12691/plant-1-3-4

Akter MS, Ahmed M, Akhand M, Islam M (2008) Acute toxicity of arsenic and mercury to fresh water climbing perch, Anabas testudineus (Bloch). World J Zool 3:13-18

Amsath A, Sugumaran J, Vanitha S (2017) Effect of arsenic $\left(\mathrm{As}_{2} \mathrm{O}_{3}\right)$ on haemetological parameters of freshwater air breathing fish, Channa punctatus (Bloch). Curr Trends Biomed Eng Biosci 7:1-5 https://doi.org/10.19080/CTBEB.2017.07.555702

Ananth S, Mathivanan V, Aravinth S, Sangeetha V (2014) Impact of arsenic metal toxicant on biochemical changes in the grass carp, Ctenopharyngodon idella. Int J Mod Res Rev 2:74-78

Aruljothi B, Sivanandan M, Sankar Samipillai S (2013) Effect of arsenic on protein and carbohydrate metabolism of fresh water fish, Labeo rohita. Int J Curr Res 5:1332-1335

Beaumont MW, Butler PJ, Taylor EW (2000) Exposure of brown trout, Salmo trutta, to a sub-lethal concentration of copper in soft acidic water: effects upon muscle metabolism and membrane potential. Aquat Toxicol 51:259-272. https://doi.org/10. 1016/S0166-445X(00)00109-0

Begum G (2004) Carbofuran insecticide induced biochemical alterations in liver and muscle tissues of the fish Clarias batrachus (linn) and recovery response. Aquat Toxicol 66:83-92. https://doi.org/10.1016/j.aquatox.2003.08.002

Bergmeyer HU (1974) Methods of enzymatic analysis. Springer, Berlin

Bhavani K, Karuppasamy R (2014) Acute toxicity bioassay and behavioural changes on zebrafish, Danio rerio (Hamilton) under arsenic trioxide. Int J Mod Res Rev 2:40-46

Bücher T, Pfleiderer G (1955) Pyruvate kinase from muscle:phosphokinase, pyruvic phosphoferase, phosphopyruvate transphosphorylase, phosphate-transferring enzyme II, etc. Phosphoenolpyruvate + ADP $\rightleftharpoons$ Pyruvate + ATP. In: Colowick SP, Kaplan NO (eds), Methods in enzymology. Academic Press, London, pp. 435-440. https://doi.org/10.1016/ 0076-6879(55)01071-9

Buckwitz D, Jacobasch G, Gerth C, Holzhütter HG, Thamm R (1988) A kinetic model of phosphofructokinase from Plasmodium berhei. Influence of ATP and fructose-6-phosphate. Mol Biochem Parasitol 27:225-232. https://doi.org/10.1016/01666851(88)90041-2

Carvalho CS, Fernandes MN (2008) Effect of copper on liver key enzymes of anaerobic glucose metabolism from freshwater tropical fish Prochilodus lineatus. Comp Biochem Physiol A: Mol Integr Physiol 151:437-442. https://doi.org/10.1016/j. cbpa.2007.04.016

Connett RJ, Sahlin K (1996) Control of glycolysis and glycogen metabolism. Compr Physiol 2011, Supplement 29: handbook of physiology, exercise: regulation and integration of multiple systems: 870-911 https://doi.org/10.1002/cphy.cp120119

David GF, Herbert J, Wright GD (1973) The ultrastructure of the pineal ganglion in the ferret. J Anat 115:79-97

Froese R, Pauly D (Eds) (2018) Fishbase: World Wide Web electronic publication. Available at: http://www.fishbase.org

Govind P, Madhuri S (2014) Heavy metals causing toxicity in animals and fishes. Res J Anim Vet Fish Sci 2:17-23. 10.2320-6535

Hacker JH, Bannasch P, Columbano A (1990) Effect of lead nitrate on liver carbohydrate enzymes and glycogen content in the rat. Carcinogenesis 11:2199-2204. https://doi.org/10.1093/carcin/11.12.2199

Haniffa M, Sridhar S (2002) Induced spawning of spotted murrel (Channa punctatus) and catfish (Heteropneustes fossilis) using human chorionic gonadotropin and synthetic hormone (ovaprim). Vet Arch 72:51-56

Haque MS, Roy SK, Islam MA, Roy N (2009) Role of arsenic on the regulation of glycogen metabolism in liver of Taki fishes (Channa punctatus) exposed to cold. Thai J Agric Sci 42:159-166

Hedayati A, Jahanbakhshi A, Shaluei F, Kolbadinezhad SM (2013) Acute toxicity test of mercuric chloride $\left(\mathrm{HgCl}_{2}\right)$, lead chloride $\left(\mathrm{PbCl}_{2}\right)$ and zinc Sulphate $\left(\mathrm{ZnSO}_{4}\right)$ in common carp (Cyprinus carpio). J Clin Toxicol 03:1-4. https://doi.org/10.4172/21610495.1000156

Hollis L, Hogstrand C, Wood CM (2001) Tissue-specific cadmium accumulation, metallothionein induction, and tissue zinc and copper levels during chronic sublethal cadmium exposure in juvenile rainbow trout. Arch Environ Contam Toxicol 41:468-474. https://doi.org/10.1007/s002440010273

James R, Sampath K, Alagurathinam S (1996) Effects of lead on respiratory activity, glycogen and blood sugar levels of the teleost Oreochronmis mossambicus (Peters) during accumulation and depuration. Asian Fish Sci 9:87-100

Jha BR, Rayamajhi A (2010) Heteropneustes fossilis. In: IUCN 2013. IUCN red list of threatened species. Version 2013.1 www. iucnredlist.org 
Karbassi AR, Bayati I, Moattar F (2006) Origin and chemical partitioning of heavy metals in riverbed sediments. Int J Environ Sci Technol 3:35-42. https://doi.org/10.1007/BF03325905

Kavidha K, Muthulingam M (2014) Lead acetate induced glycogen level alterations in gill and kidney tissues of freshwater fish Cyprinus carpio (Linn.). Int J Mod Res Rev 2:517-521

Klein HW, Palm D, Helmreich EJM (1982) General acid-base catalysis of $\alpha$-glucan phosphorylases: stereospecific glucosyl transfer from D-glucal is a pyridoxal $5^{\prime}$-phosphate and orthophosphate (arsenate) dependent reaction. Biochemistry 21:6675-6684. https://doi.org/10.1021/bi00269a010

Lagunas R (1980) Sugar-arsenate esters: thermodynamics and biochemical behavior. Arch Biochem Biophys 205:67-75. https:// doi.org/10.1016/0003-9861(80)90084-3

Lepper TW, Oliveira E, Koch GDW, Berlese DB, Feksa LR (2010) Lead inhibits in vitro creatine kinase and pyruvate kinase activity in brain cortex of rats. Toxicol Vitr 24:1045-1051. https://doi.org/10.1016/J.TIV.2009.11.012

Macirella R, Guardia A, Pellegrino D, Bernabò I, Tronci V, Ebbesson LOE, Ebbesson LOE, Tripepi S, Brunelli E (2016) Effects of two sublethal concentrations of mercury chloride on the morphology and metallothionein activity in the liver of zebrafish (Danio rerio). Int J Mol Sci 17:1-16. https://doi.org/10.3390/ijms17030361

Moon TW, Foster GD, Plisetskaya EM (1989) Changes in peptide hormones and liver enzymes in the rainbow trout deprived of food for 6 Weeks. Can J Zool 67:2189-2193

OECD (1992) Fish, acute toxicity test. In: Guideline for the testing of chemicals, pp. 1-9. http://dx.doi.org/10.1787/ 9789264069961-en

Ohe T, Watanabe T, Wakabayashi K (2004) Mutagens in surface waters: a review. Mutat Res 567:109-149. https://doi.org/10. 1016/J.MRREV.2004.08.003

Parvin E, Ahmed K, Islam M, Salma M, Alamgir A (2011) Preliminary acute toxicity bioassays of lead and cadmium on fresh water climbing perch, Anabas testudineus (Bloch). Terr Aquat Environ Toxicol 5:55-58

Passonneau JV, Rottenberg DA (1973) An assessment of methods for measurement of glycogen synthetase activity including a new direct one-step assay. Anal Biochem 51:528-541. https://doi.org/10.1016/0003-2697(73)90510-1

Patel J, Rana K, Prasad B (2017) Effects of arsenic trioxide on poecilia sphenops. Res J Chem Environ Sci 5:59-64

Raibole M, Shaffi SA, Raibole M (2013) Influence of selenium on lead caused variations of phosphofructokinase in different brain regions of fresh water teleosts. Int J Sci Res 2:61-64

Reynolds ES (1963) The use of lead citrate at high pH as an electron-opaque stain in electron microscopy. J Cell Biol 17:208-212. https://doi.org/10.1083/jcb.17.1.208

Roesijadi G (1992) Metallothioneins in metal regulation and toxicity in aquatic animals. Aquat Toxicol 22:81-113. https://doi.org/ 10.1016/0166-445X(92)90026-J

Russell EL, Storey KB (1995) Anoxia and freezing exposures stimulate covalent modification of enzymes of carbohydrate metabolism in Littorina littorea. J Comp Physiol B 165:132-142. https://doi.org/10.1007/BF00301477

Sadeghi A, Imanpoor MR (2015) Acute toxicity of mercuric chloride $\left(\mathrm{HgCl}_{2}\right)$, lead chloride $\left(\mathrm{PbCl}_{2}\right)$ and zinc sulfate $\left(\mathrm{ZnSO}_{4}\right)$ on silver dollar fish (Metynnis fasciatus). Iran J Toxicol 9:1301-1306

Sastry KV, Subhadra K (1982) Effect of cadmium on some aspects of carbohydrate metabolism in a freshwater catfish Heteropneustes fossilis. Toxicol Lett 14:45-55

Seifter S, Dayton S, Novic B, Muntwyler E (1949) The Estimation of glycogen with the Anthrone reagent. Arch Biochem 8:191-200

Soengas JL, Agra-Lago MJ, Carballo B, Andrés MD, Veira JAR (1996) Effect of an acute exposure to sublethal concentrations of cadmium on liver carbohydrate metabolism of Atlantic Salmon (Salmo salar). Bull Environ Contam Toxicol 57:625-631. https://doi.org/10.1007/s001289900236

Thang NQ, Huy BT, Van Tan L, Phuong NTK (2017) Lead and arsenic accumulation and its effects on plasma cortisol levels in Oreochromis sp. Bull Environ Contam Toxicol 99:187-193. https://doi.org/10.1007/s00128-017-2113-7

Velez D, Montoro R (1998) Arsenic speciation in manufactured seafood products: a review. J Food Prot 61:1240-1245

Vijaykumar C, Sridhar S, Haniffa MA (1998) Low cost breeding and hatching techniques of the Catfish, Heteropneustes fossilis for small-scale farmer. Naga 21:15-17

Vinodhini R, Narayanan M (2009) Biochemical changes of antioxidant enzymes in common carp (Cyprinus Carpio L.) after heavy metal exposure. Turkis J Vet Anim Sci 33:273-278. https://doi.org/10.3906/vet-0711-18

Wennberg A (1994) Neurotoxic effects of selected metals. Scand J Work Environ Health 20:65-71

Yun SW, Hoyer S (2000) Effects of low-level lead on glycolytic enzymes and pyruvate dehydrogenase of rat brain in vitro: relevance to sporadic Alzheimer's disease? J Neural Transm 107:355-368. https://doi.org/10.1007/s007020050030

\section{Publisher's Note}

Springer Nature remains neutral with regard to jurisdictional claims in published maps and institutional affiliations. 